\title{
Kümeleme analiz yöntemi kullanılarak Pamukkale Üniversitesi Hastaneleri’nde poliklinik hizmeti veren bölümlerin hasta özelliklerine göre gruplanması
}

\section{Grouping the departments providing outpatient services in Pamukkale University Hospitals according to patient characteristics by using cluster analysis method}

\author{
Murat Taşer, Özer Öztekin
}

Gönderilme tarihi:01.11.2021

Kabul tarihi:25.01.2022

\section{Öz}

Amaç: Son yıllarda sağlık sektöründe üçüncü basamak hastanelerden tanı ve tedaviye yönelik beklenen multidisipliner yaklaşım hizmetleri giderek artmaktadır. Bu durum hastanelerde birden fazla birime müracaat gerektirmekte, bu da hastaların sonuca ulaşmada aşırı zaman kaybetmelerine ve tanı/tedavilerde gecikmelere neden olmaktadır. Bu sürecin kısaltılmasının ilk ve kolay yöntemlerinden birisi benzerlik gösteren ve iş birliği gerektiren bölümlerin birbirlerine yakın konumlandırılmasıdır.

Bu çalışmada Pamukkale Üniversitesi Hastanelerinde hasta gruplarına, tanılara ve işlem türlerine göre farklılık ve benzerlik gösteren hastane bölümlerinin ortaya konulması, belirlenen ihtiyaçlarına göre de çözüm önerilerinin tanımlanması amaçlanmıştır.

Gereç ve yöntem: Çalışma kümeleme analizi yöntemiyle 2019 yılında hastaneye gelmiş olan toplam 717.771 hasta üzerinden gerçekleştirilmiştir. Yirmi dokuz bölüme ait 9 farklı değişken (hasta sayısı, ortalama yaş, kanser hastaları oranı, mavi kart hasta oranı, kas iskelet sistemi ve bağ dokusu hastalıkları tanı grubuna dâhil hasta oranı, dolaşım sistemi hastalıkları tanı grubuna dâhil hasta oranı, genitoüriner sistem hastalıkları tanı grubuna dâhil hasta oranı, laboratuvar incelemesine giden hasta oranı ve radyolojik görüntülemeye giden hasta oranı) bilgisi kullanılarak toplam 9 adet küme bilgisi elde edilmiştir.

Bulgular: Değişkenlere göre dokuz küme (Küme 1 Endokrinoloji, İç Hastalıkları, Romatoloji, Hematoloji; Küme 2 Kalp Damar Cerrahisi, Kardiyoloji; Küme 3 Üroloji, Nefroloji; Küme 4 Beyin Cerrahi, Fizik Tedavi, Ortopedi; Küme 5 Çocuk Cerrahi, Çocuk Hastalıkları, Genel Cerrahi, Kadın Doğum; Küme 6 Girişimsel Radyoloji, Tıbbi Genetik, Göz Hastalıkları, Kulak Burun Boğaz, Plastik Cerrahi; Küme 7 Göğüs Hastalıkları, Göğüs Cerrahi; Küme 8 Enfeksiyon Hastalıkları, Gastroenteroloji, Aile Hekimliği, Dermatoloji, Nöroloji; Küme 9 Radyasyon Onkolojisi, Tıbbi Onkoloji) elde edilmiş olup, Küme 3 haricinde diğer 8 kümenin mevcut hastane düzenine tamamen veya kısmen uyumlu olduğu görülmüştür.

Sonuçlara göre hasta sayısı yüksek olan dört kümeden sadece biri mevcut durumda hastane girişine yakın lokasyonda bulunmaktadır. Diğer üç kümede ise hasta sayısının dengelenmesi amacıyla, küme elemanlarından bazılarına bir alt veya üst katta yer aldığı gözlenmektedir. Bu durum elde edilen analiz sonuçlarının mimari yapıya uygun hale getirilmesi şeklinde yorumlanabilir. Mevcut uygulamada, kanser tanılı ve çocuk hastaların yoğun bulunduğu kümelere karşılık gelen yerleşimlerde eksiklikler tespit edilmiştir.

Sonuç: Mevcut fiziksel yerleşimin analiz sonuçlarıyla tam olarak olmasa da büyük ölçüde uyum gösterdiği belirlenmiştir. Elde edilen bulguların belirtilen sınırlılıklar göz önünde bulundurularak diğer bölge veya üniversite hastanelerinde karar-destek verisi olarak kullanılmasının faydalı olacağını düşünmekteyiz.

Anahtar kelimeler: Veri madenciliği, hasta profili, kümeleme analizi, sağlık yönetimi, poliklinik yerleşimi.

Taşer M, Öztekin Ö. Kümeleme analiz yöntemi kullanılarak Pamukkale Üniversitesi Hastaneleri'nde poliklinik hizmeti veren bölümlerin hasta özelliklerine göre gruplanması. Pam Tıp Derg 2022;15:251-266.

\begin{abstract}
Purpose: In recent years, the multidisciplinary approach services expected from tertiary hospitals in the health sector for diagnosis and treatment have been increasing. This situation requires applying to more than one unit in hospitals, which causes patients to lose excessive time in reaching the result and delays in diagnosis / treatment. One of the first and easy ways to shorten this process is to position similar and collaborative departments close to each other. In this study, it is aimed to reveal the hospital departments that show differences and similarities in Pamukkale University Hospitals according to patient groups, diagnoses and types of procedures, and to define solution proposals according to their identified needs.

Materials and methods: The study was carried out on a total of 717,771 patients who came to the hospital in 2019 with the cluster analysis method. A total of 9 cluster information was obtained by using 9 different variables (number of patients, average age, ratio of cancer patients, ratio of blue card patients, ratio of patients included
\end{abstract}

Murat Taşer, Pamukkale Üniversitesi Hastaneleri, Başmüdürlük, Denizli, Türkiye, e-posta: mtaser@pau.edu.tr (https://orcid.org/0000-00016871-4171) (Sorumlu Yazar)

Özer Öztekin, Prof. Dr. Pamukkale Üniversitesi Tıp Fakültesi, Kadın Hastalıkları ve Doğum Anabilim Dalı, Denizli, Türkiye, e-posta: ooztekin@ pau.edu.tr (https://orcid.org/0000-0002-1686-5418) 
in the diagnosis group of musculoskeletal and connective tissue diseases, ratio of patients included in the diagnosis group of circulatory system diseases, ratio of patients included in the diagnosis group of genitourinary system diseases, patients who went to laboratory examination rate and rate of patients going to radiological imaging) belonging to 29 departments.

Results: Nine clusters according to variables (Cluster 1 Endocrinology, Internal Medicine, Rheumatology, Hematology; Cluster 2 Cardiovascular Surgery, Cardiology; Cluster 3 Urology, Nephrology; Cluster 4 Neurosurgery, Physical Medicine and Rehabilitation, Orthopedics; Cluster 5 Pediatric Surgery, Pediatrics, General Surgery, Obstetrics and Gynecology, Cluster 6 Interventional Radiology, Medical Genetics, Ophthalmology, Otolaryngology, Plastic Surgery; Cluster 7 Chest Diseases, Thoracic Surgery; Cluster 8 Infectious Diseases, Gastroenterology, Family Medicine, Dermatology, Neurology; Cluster 9 Radiation Oncology, Medical Oncology) were obtained, and it was observed that 8 other clusters, except for Cluster 3 , were fully or partially compatible with the existing hospital layout.

According to the results, only one of the four clusters with high patient numbers is currently located near the entrance. In the other three clusters, it is observed that some of the cluster elements are placed on the lower or upper floor in order to balance the number of patients, and this can be interpreted as making the analysis results suitable for the architectural structure. In the current practice, deficiencies have been identified in the settlements of clusters where cancer patients and pediatric patients are concentrated.

Conclusion: It has been determined that the existing physical settlement is in good agreement with the analysis results, although not completely. Considering the limitations stated, there is no obstacle to using the findings as decision support data in other regional or university hospitals.

Key words: Data mining, patient profile, cluster analysis, healthcare management, outpatient clinic location.

Taser M, Oztekin O. Grouping the departments providing outpatient services in Pamukkale University Hospitals according to patient characteristics by using cluster analysis method. Pam Med J 2022;15:251-266.

\section{Giriş}

Hastanelerde kimi zaman gün içerisinde poliklinik, laboratuvar ve radyolojik görüntüleme birimlerine binlerce hasta muayene olmak için gelmektedir. Bazen bir ilçe merkezi kadar nüfus barındıran hastanelerin yönetim etkinliği açısından fiziksel organizasyonlarının düzgün bir şekilde yapılması gerekmektedir. Hastane içinde gereksiz yere çok uzun mesafeler dolaşan hastalar güvenlik, hijyen, gürültü ve karmaşa gibi ek problemlere yol açmaktadır. $\mathrm{Bu}$ ek problemler de fazladan temizlik, güvenlik, danışma ve sekreter elemanı intiyacı doğurmaktadır [1].

Pek çok bölüm ve çok katlı ünitelerden oluşan hastanelerin, hasta akışına uygun organize edilmesi ve benzer hasta profillerine uygun yerleşim planlarına sahip olması gerekmektedir. Yoğun hasta sayısı, eksik ya da hatalı hasta yönlendirmesi, hastane içindeki ve koridorlardaki trafik akışını olumsuz etkilemektedir. Buna ek olarak kötü yerleşim tercihleri hastaların hastane içindeki bekleme sürelerini uzatmakta, koridorlarda istenmeyen bir yoğunluğa yol açmaktadır [2].

Bu yoğunluktan dolayı artan gürültü seviyesi, düzensizlik ve karmaşa, hastalarda zaten hastalık nedeniyle mevcutta var olan stres, korku, endişe seviyesini yükseltmekte, bunun sonucu olarak ta memnuniyetsizlik, şikâyet ve çatışma eğilimleri artmaktadır. Aynı durumun hastane çalışanlarına da aksetmesi sıkkınlık, bezginlik, yorgunluk, stres, tükenmişlik ve işten ayrılma isteği gibi verimsizlik nedenlerine yol açmaktadır [1].

Çözüm aynı ya da yakın işlevli olan ünitelerin birlikte konumlandırılmasından geçmektedir. Birlikte konumlandırma, birbirine benzer hasta profiline sahip polikliniklerin en yakın şekilde yerleştirilmesidir. Ek olarak laboratuvar, radyoloji gibi birimlere en çok hasta yönlendiren bölümlerin, bu birimlere yakın konumlandırılması, hastalar ve çalışanlar için maksimum faydayı sağlayacak şekilde yerleşim planının ayarlanması gerekir. Bu plan ise ancak hastane otomasyon sisteminden hasta akışıyla ilgili elde edilecek doğru bilgiler ışığında ayarlanabilir [3].

Hem rahatsızlığı ile ilgili bölümlere hem de radyoloji, laboratuvar gibi işlem birimlerine hastane içinde çok dolaşmadan kolaylıkla ulaşarak işlerini hızlıca bitiren hastaların memnuniyeti tabi ki yüksek olacaktır. Bu durum hastaların hastaneye bağlıı̆ını da artıracaktır. $\mathrm{Bu}$ yönde alınacak önlemler, tüm teşhis ve tedavi ünitelerinin yanı sıra bunlara destek olan teknik ve idari birimlerinin işletilmesi için gerekli personel kaynağının da (doktor, yardımcı sağlık ve destek personeli) etkin bir 
şekilde kullanılabilmesini sağlayacaktır. İleri teknolojik yüksek maliyetli tıbbi cihazların ortak kullanımlarını da kolaylaştıracaktır.

Etimesgut Askeri Hastanesi temel alınarak yapılan bir çalışmada, LayOPT programı kullanılarak 17 farklı polikliniğin birbirlerine olan hasta sevki sayıları incelenmiş ve hastane yerleşimi içerisinde genel bir optimizasyon sağlanmaya çalışılmıştır. Çalışma sonucunda \%58 lik bir maliyet azalması sağlanabileceği ifade edilmiştir [2]. Çalışma poliklinik yerleşimleri için örnek kabul edilebilir olsa da, kapsam olarak sadece polikliniklerin birbirlerine sevk sayılarını içermektedir.

Kokoç [4] tarafından Kırıkkale Üniversitesi Tıp Fakültesi Hastanesi Acil Servis bölümünde yapılan çalışmada, Acil servisin departmanları arasındaki hasta akışları dikkate alınarak, yürüyüş mesafelerinin ve bekleme sürelerinin azaltılması amacıyla yerleşim düzeni incelenmiştir. Birliktelik analizi algoritmaları aracılığıyla hasta akışı incelenerek birbirine yakın olması gereken, girişe yakın olması gereken ve merkezi konumda bulunması gereken departmanlar belirlenmiştir. Oluşturulan alternatif yerleşim düzeninde, diğer bölümlerle en fazla ilişkiye sahip olduğu düşünülen Radyoloji bölümü, tüm bölümlerin ortasında olacak şekilde konumlandırılmıştır. Böylece hastaların buraya ulaşım süresi ve mesafesi kısaltılmak istenmiştir.

Çetik ve Oğulata [3] tarafından yapılan çalışmada ise hastanenin hizmet birimleri arasındaki iş akışı ergonomik açıdan incelenmiştir. Çalışmada hastanelerin mimari proje hatalarından ve yöneticiler tarafından objektif olmayan kriterlere göre yerleşim yapılmasından dolayı verimsiz hale geldiği ifade edilmiştir. Yaşlı ve ağır hastaların polikliniklere ulaşmasının zor olmasının da hastaların poliklinik hasta trafiği için şikâyetçi olduğu konuların başında gelmekte olduğu yine bu çalışmada belirtilmektedir.

$\mathrm{Bu}$ çalışmada, literatürden örnekleri verilenlerden farklı olarak poliklinikte hizmet verilen hasta gruplarına, tanılara ve işlem türlerine göre farklılık ve benzerlik gösteren hastane bölümlerinin ortaya konulması amaçlanmıştır. Bu sayede benzer hasta profiline sahip bölümlerin hastane içi yerleşiminde uygun blok ve katlara yerleştirilmesi sağlanabilir. Bu durum hasta ulaşımlarının kolay ve rahat bir şekilde sağlanabilmesi için intiyaç duyulan bilgiyi sağlayacaktır. Ek olarak özel önem gösterilmesi gereken hasta profillerinin (kanser hastaları gibi) sıklıkla gittiği bölümlerden oluşan kümeler, buraya özel olarak tahsis edilecek sekretarya, hemşire ve diğer personellerle desteklenebilir.

\section{Çalışmada ayrıca aşağıda belirtilen alt amaçlara ulaşılmaya çalışılmıştır.}

1. Pamukkale Üniversitesi Hastaneleri poliklinik hizmeti veren bölümlerin mevcut fiziksel yerleşiminin, yapılan analiz sonuçlarına uygun olup olmadığının ortaya konması.

2. Yapılabilecek muhtemel bir bölüm yerleşim değişikliğinin, uygun poliklinik kümelerine ve hasta gruplarına göre oluşturulmasına yardım edilmesi.

3. Ayrıca bölgedeki hasta profillerinin benzer olacağı varsayımıyla çalışmada elde edilen bulgularla, bölgede yapılacak hastanelerin poliklinik yerleşimleri sırasında üst yöneticilere karar destek bilgisi sağlanması.

4. Araştırma sonuçlarına göre asansör, tekerlekli sandalye, sedye vb. gibi mobilize olmayan hastalar için önem arz eden alet ve cihazların bekleme bölgelerinin belirlenebilmesi.

\section{Gereç ve yöntem}

Araştırmada, Pamukkale Üniversitesi Hastaneleri 33 Anabilim/Bilim Dalı ayaktan hastalarının, demografik ve tetkik istem bilgilerine göre gruplandırıması amacıyla kümeleme analizi metodu kullanılmıştır. Kullanılan veriler Pamukkale Üniversitesi Hastaneleri Hastane Bilgi Yönetim Sistemi (HBYS) veri tabanından elde edilmiştir. Pandemiden dolayı 2020 yılına ait veriler bölüm bazında değişkenlik gösterebilmektedir. Bundan dolayı veri tabanından değişkenlerin çıkarılmasında 2019 yılı tercih edilmiştir. Veriler bu dönemdeki mevcut durumu göstermektedir. Yani çalışma bir kesit çalışması niteliğindedir. Hastaların ilk muayene sonrasında oluşan kontrol muayeneleri mükerrer olduğu için dikkate alınmamıştır. Elde edilen veriler, Statistical Package for the Social Sciences (SPSS) 21 paket programı yardımıyla analiz edilmiştir.

Sağlık sektöründeki işlemlerde üretilen büyük miktarlarda veriler, geleneksel yöntemlerle analiz edilemeyecek kadar zor ve karmaşıktır. 
Veri madenciliği bu veri yığınlarının daha kolay anlaşılabilmesi için metodoloji ve teknoloji sağlar. Sağlık yönetimini kolaylaştırmak, hastanelere başvuruları yönetmek ve azaltmak, hastalıkları daha iyi tanılamak, yüksek riskli ve kronik hastaları izlemek veri madenciliğinin sağlık alanında uygulama alanlarındandır [5]. Çalışmada da poliklinik hizmeti veren bölümlerin gruplara ayrılması için veri madenciliği yöntemlerinden kümeleme analizi kullanılmıştır.

Kümeleme analizi yönteminde grup sayısı bilinmeyen birimler, benzerliklerine göre sınıflandırılır. Örneğin anket yöntemiyle büyük ölçekte veri toplayan araştırmacılar, elde ettikleri verilerin gruplandırılmasını ve anlamlandırılmasını sağlayabilirler. Aynı zamanda yakınlıkları ağaç biçiminde görüntüleyerek, küçük kümeler halinde birbirine uyumlu anlamlı gruplar oluşturabilirler. Bu yöntemin amacı, birimlerin belirlenen değişkenler yönünden birbirine en çok benzeyenlerinin aynı küme içerisinde yer almasını sağlayacak şekilde sınıflandırılmasıdır. Böylece benzer sınıflara giren birimler birlikte incelenerek belli prototipler tanımlanabilir [6]. Önemli bir veri madenciliği aracı olarak diğer yöntemlerden farkı, daha önce tanımlanmamış sınıflandırmalara dayanmasıdır. Bir popülasyondan alınan $\mathrm{n}$ tane birimin $p$ tane değişkene ait gözlemlerinden, homojen olanlarını bir araya getirerek heterojen gruplar oluşturur [7, 8]. Oluşan sınıflandırma/ gruplandırma araştırmacı için özet bilgiler sunar. Bu yöntemle, gözlemlenen nesnelerin ölçülecek değişkenler üzerindeki değerleri hesaplanarak oluşan gruplara odaklanılır. Kümeleme analizinde gruplandırma yapmak için nesnelerin uzaklık, korelasyon ya da benzerlik ölçümleri kullanılmaktadır. Önceden belirlenen seçme kriterlerine göre hastalar, ürünler, müşteriler gibi nesne ya da kişilerden birbirine çok benzeyen gruplar aynı küme içinde toplanır. Analiz bitiminde oluşan kümeler arasında benzerlik yani homojenlik çok düşükken farklılık yani heterojenlik çok yüksektir [9].

Kümeleme analizinde iki farklı teknik kullanılır. Hiyerarşik kümeleme tekniği, birimleri birbirlerine olan uzaklık (benzeşmezlik) ve yakınlıklarına (benzerliklerine) göre farklı aşamalarda birleştirerek kümeler oluşturur. Birimlerin hangi düzeyde küme elemanı olduğunu da belirler. Hiyerarşik kümelemede tek bağlantı, tam bağlantı, ortalama bağlantı,
Ward's (varyans) ve merkezi bağlantı yöntemleri uygulanır. Örnek olarak literatürde sıklıkla kullanılan varyans tekniğinde, küme ortasına düşen gözlemin aynı küme içindeki diğer gözlemlerden ortalama uzaklığı esas alınır ve toplam sapma karelerinden yararlanılır $[8,10,11]$. İkinci teknik olan Hiyerarşik olmayan kümeleme, genel olarak daha büyük veri setlerine uygulanır ve araştırmacının anlamlı olabilecek küme sayısı hakkında bir ön bilgisi varsa kullanılır. K- ortalama, medoid, yığma ve bulanık kümeleme hiyerarşik olmayan yöntemlerdendir [7, 12]. Kümeleme analizi yapılırken ilk aşamada benzerlik ya da uzaklık ölçüsünden biri (kareli öklid uzaklığı gibi) seçilir. Sonra kullanılacak tekniğe (hiyerarşik ve hiyerarşik olmayan) karar verilir. Üçüncü aşamada seçilen tekniğe uygun kümeleme yöntemi türü seçilir (hiyerarşik - centroid). Son aşamada ise küme sayısı belirlenir ve sonuçlar yorumlanır [13].

Çalışmada uzaklık matrisinin belirlenmesinde kareli öklit uzaklığı (squared euclidiean distance) kullanılmıştır. Bölümlere ait kümelerin oluşturulmasında ise oluşacak küme sayısına dair herhangi bir ön bilgi olmadığından dolayı hiyerarşik kümeleme tekniği kullanılmıştır. Hiyerarşik kümeleme analizi yöntemlerinden ise literatürde sıklıkla kullanılan Ward's metodu uygulanmıştır. Küme sayısının belirlenmesinde sıklıkla izlenen yol ağaç grafiğinin (dendrogram) incelenmesidir. Bu yöntemde analiz sonunda çıkan ağaç grafiği incelenerek en uygun kümeleme sonucuna karar verilir. Çalışmada da küme sayısına ağaç grafiği yardımıyla karar verilmiştir.

Analize geçmeden önce çalışmanın kapsamına giren bölümler incelenmiştir. Poliklinik hizmeti veren bölümlerden direkt hasta muayene etmeyen ancak diğer bölümlerden tetkik istenmesi durumunda işlem yapan Radyoloji, Nükleer Tıp, Patoloji bölümleri kapsamdan çıkarılmıştır. Çalışmada yardımcı hizmet alanları şeklinde nitelendirebileceğimiz bu bölümlerden, istenen tetkik sayısı bazında diğer bölümlerin yararlanma oranı da değişken olarak kullanılmıştır. Ancak sadece radyoloji bölümüne yapılan istem sayısı anlamlı kabul edilerek diğer bölümlerin gruplandırılması için kümeleme analizine eklenmiştir. Böylece Radyoloji bölümü verileri, buradan istem yapan bölümlerin gruplandırılmasına yardımcı olması 
amacıyla kullanıımıştır. Ayrıca çalışmanın amacı benzer hasta profiline sahip hastaların aynı blok ve katlara yönlendirilmesi, bu sayede hasta ulaşımlarının kolay ve rahat bir şekilde yapılması olduğu için az sayıda poliklinik hizmeti olan Adli Tıp ve Anestezi ve Reanimasyon bölümleri de kapsam dışı bırakılmıştır. Hastaları acil girişinden başvuran, ayrı bir ekiple desteklenen Acil Tıp bölümü de çalışma amacına uymadığı için kapsam dışı bırakılmıştır. Kapsam dışı bırakılan diğer bölümler ise Psikiyatri ve Çocuk Psikiyatrisi'dir. Hasta özelliklerinden dolayı diğer hastalardan ayrıştığı ve mevcut durumda da ayrı bir lokasyonda konumlandığı için bu bölümler kapsam dışı bırakılmışlardır. Karar verilmesi gereken önemli noktalardan biri de araştırmanın amacına ulaşılabilmesi için analizde kullanılması gereken değişkenlerin belirlenmesidir. Çalışmada benzer hasta tiplerinin oluşturulması adına değişken seçimi için hasta tanı, demografik ve tetkik istem verilerinden yararlanılmıştır. Değişkenlerin içeriğiyle ilgili detaylı bilgi, veri seti bölümünde verilmiştir.

Çalışmada, her bir değişkenin bölümlere ait verileri ve analizde çıkan sonuçlar konunun uzmanı, doktor ve hastane yöneticileri tarafından değerlendirilmiş olup, farklı değişkenler eklenerek veya var olanlardan anlamsız sonuçlar verenler çıkarılarak, kümelenmeler değişik açılardan tekrar tekrar incelenmiştir. Çalışma için Pamukkale Üniversitesi Girişimsel Olmayan Klinik Araştırmalar Etik Kurulu'ndan onay alınmıştır.

\section{Veri seti}

Çalışmanın bu bölümünde analiz için kullanılacak veri seti ayrıntıları ve analize hazırlanma aşamaları konu edilmiştir. Analizde toplam 29 bölüme ait 9 farklı değişken bilgisi kullanılmıştır. Kullanılan değişkenlerden farklı olarak, çalışmada anlamsız sonuçlar, eksik veya hatalı veri girişlerden dolayı kullanılamayan 8 ayrı değişkenin verileri de sistemden çekilerek incelenmiştir. Veriler hastane bilgi yönetim sisteminin veri tabanına ulaşım hakkı bulunan bilgi işlem personeli tarafından SQL (Structured Query Language) sorgulama dili kullanılarak elde edilmiştir. Değişkenler bazında elde edilen veriler öncelikle Microsoft Excel tablolama programına aktarılmış, sonra verilerin analize uygun hale getirilmesi amacıyla kapsamlı bir temizlik aşamasından geçirilmiştir. İlk aşamada çalışma kapsamında yer almayan bölüm kayıtları 2019 yılına ait değişken bazıı veri setinden çıkarılmıştır. Sonraki aşamada çalışmada ayaktan ilk başvuran hastaların bilgilerinin analiz edilmesi amaçlandığı için yatan hasta ünitelerine ait veriler ve ayaktan kontrol hastaları veriler içerisinden çıkarılmıştır. Eksik ve doğrulanamayan verilerin temizlenmesi aşamalarının da tamamlanmasından sonra 2019 yılına ait toplam 717.771 hasta üzerinde çalışmaya geçilmiştir.

Çalışmada ilk etapta değişken olması için planlanan verilerden bazıları hastane sisteminden elde edilemezken bazılarının ise yeterli miktarda kayda sahip olmadığı görülmüştür. Kullanım için incelenen 17 değişkenden bazılarının ise analiz sonucunda anlamlı sonuçlar vermediği görülmüş ve çalışmadan çıkarılmıştır.

Analizde kullanılan değişkenler Laboratuvar tetkiki yapılan hastaların oranı, Radyoloji çekimi yapılan hasta oranı, Mavi kartlı hastaların oranı, Yaş ortalaması, Kanserli hastaların oranı (C tanı grubu), M (Kas iskelet sistemi ve bağ dokusu hastalıkları), I (Dolaşım sistemi hastalıkları) ve N (Genitoüriner sistem hastalıkları) tanı gruplarına ait hastaların oranlarıdır. Ayrıca bölüm toplam hasta sayıları, tüm bu değişkenlerin toplam sayıya oranlarının bulunması amacıyla kullanılmıştır.

Kapsam dışı bırakılan değişkenler ise patoloji tetkiki yapılan hastaların oranı, şehir dışından gelen hastaların oranı, aynı gün içinde diğer bölümlerden gelen hastaların oranı, Grafi, MR (Manyetik Rezonans), BT (Bilgisayarlı Tomografi), Ultrason ve Nükleer Tıp çekimi yapılan hastaların oranlarıdır.

Sonuç olarak birbirine benzerlik gösteren bölümlerin aynı gruplarda kümelenmesini sağlayacağı düşünülen dokuz farklı değişken kullanılmıştır. Değişkenlerin analize katılması noktasında her bir değişkene ait hasta sayısının bölüm toplam hasta sayısına yüzdelik oranı kullanılmıştır. Örneğin Endokrinoloji'den Laboratuvar tetkiki için yönlendirilen hasta sayısının (tekrarlar çıkartılmış) toplam bölüm hasta sayısına yüzde oranı belirlenerek analize katılmıştır. Bu sayede aynı hasta profiline sahip bölümlerin aynı gruplarda yer alması sağlanmıştır. Eğer belirtilen değişkenlerin salt hasta sayısı alınmış olsaydı, fazla hasta bakan 
bölümlerin değişkenlere ait sayıları da fazla olacağından, her değişken değerlendirmesinde ön plana çıkarak uygun bir değerlendirme yapılamamasına yol açılacaktı. Sadece yaş değişkeninde hasta yaşları toplamı, hasta sayısına bölünerek bölüm hasta yaş ortalaması bulunmuş ve analize katılmıştır.

Çalışmada kullanılan veya kullanılmak üzere incelenen ancak daha sonra çeşitli sebeplerden kapsam dışı bırakılan değişkenler ve kapsam dışı bırakılma sebepleri aşağıda verilmiştir.

Laboratuvar tetkiki yapılan hastaların oranı (\%): Poliklinik hizmeti verilirken bölümlerin neredeyse tamamından tanılama amaçlı laboratuvar tetkiki istemi yapılabilmektedir. Ancak bu durum, bazı bölümlerde her gelişinde tekraren istem yapılarak yoğun bir şekilde olurken, bazı bölümlerde daha az olabilmektedir. Bölümlerden kan alma, idrar numunesi verme gibi alanlara az ya da çok hasta akışına yol açmaktadır. Değişken, numune alma alanları ile poliklinikler arasındaki hasta akışının düzenli bir şekilde sağlanması adına analize eklenmiştir. Laboratuvar tetkikleri kapsamında Acil ve Rutin Biyokimya, Hormon (Hormon testleri, Tümör belirteçleri, ilaç düzeyleri), Hematoloji, idrar ve gaita analizleri bakteriyolojik ve moleküler mikrobiyoloji testleri yer almaktadır.

Çalışmada ayrıca Patoloji kodları da ayrı bir değişken olarak incelenmiş ancak doğrulanmış veriye ulaşılamadığı için kapsam dışı bırakılmıştır.

Radyolojik görüntülemesi yapılan hastaların oranı (\%): Radyolojik çekim alanları ile sık görüntüleme tetkiki isteyen poliklinikler arasındaki hasta akışının düzenli bir şekilde sağlanması, bölüm hastalarının görüntüleme alanlarına rahatlıkla ulaşmasına imkân tanıyacak bir konuma yerleştirilmesi amacıyla analize eklenmiştir.

Ayrıca Radyolojil görüntüleme kodlarının alt kırılımları olan Grafi, MR (Manyetik Rezonans), BT (Bilgisayarlı Tomografi) ve Ultrason çekim sayıları da ayrı ayrı birer değişken gibi incelenmiş, ancak anlamlı gruplandırmaya ulaşılamadığı için kapsam dışı bırakılmalarına karar verilmiştir. Ayrı bir değişken olarak incelemeye tabi tutulan Nükleer Tıp kodları da anlamlı sonuç vermediğinden çalışmadan çıkarılmıştır.
Şehir dışından gelen hastaların oranı (\%): Bölge hastanelerinin çoğu, sadece bulundukları ilin merkezine değil çevre illerden gelen hastalara da hizmet vermektedirler. Bu durumda dışarıdan gelen çoğu hasta nadir geldiği hastanede yabancılık çekmektedir. Çalışmada bu hastaların sık geldiği bölümler danışma ve bilgilendirme (pano, broşür vb.) yönünden desteklenmesi amacıyla gruplanması planlanmıştır. Ancak elde edilen sonuçların bölüm bazında birbirine yakın olması, belirgin bir farklılaşma oluşturmamasından dolayı çalışmadan çıkarılmıştır.

Mavi kartlı hastaların oranı (\%): Mavi kartlı hastalar Sağlık bakanlığı tarafından yayınlanan genelge uyarınca organ nakli olan, immün sistemi zayıf, 65 yaş üstü, engelli veya hamile gibi gerekliliklerden dolayı poliklinik hizmetlerinde öncelikli olan hastalardır. Bu hastalara gerekli özenin gösterilmesi adına değişken analize katılmıştır. Örneğin engelli hastaların sıklıkla hizmet aldığı bölümlerin belirlenmesi, buna uygun yerleşimlerin ve hizmet ayrıcalığının sağlanması gerekmektedir.

Aynı gün içinde diğer bölümlerden gelen hastaların oranı (\%): Hasta akışı sadece laboratuvara ve radyolojiye olmamakta aynı zamanda diğer bölümlerden konsültasyon ya da ikinci poliklinik girişi şeklinde de olmaktadır. Bu noktada değişken, birlikte sık çalışan bölümlerin ortaya konması amacıyla incelenmiştir. Ancak sorgu sonucu elde edilen verilerin uygun bir yöntemle doğrulanamamasından, doğrulananların ise yeterli düzeyde olmamasından dolayı bu değişken de çalışmada kapsam dışı bırakılmıştır.

Kanserli hastaların oranı (\%): Kanser tanılı hastalarözelönemgösterilmesigereken birhasta grubudur. Bu hastaların ilerleyen aşamalarda hareket kabiliyetleri sınırlanmaktadır. Sıklıkla kanser tanılı hastalara hizmet veren bölümlere ve bu bölümlerden de numune verilen ya da çekim yapılan ünitelere kolaylıkla ulaşılabilir olması gerekmektedir. Ayrıca içinde bulundukları sıkıntılı durumdan dolayı psikolojik olarak yıpranmış olabilmektedirler. $\mathrm{Bu}$ tarz hastalara hizmet veren personelinde özel seçilmesi ve belirli periyotlarla eğitime tabi tutulması gerekmektedir. Bu değişken de analize katılmıştır. 
Benzer tanı grubuna ait hastaların oranı (\%): Çalışma kapsamında ICD 10 (Hastalıkların ve Sağlıkla Illgili Sorunların Uluslararası İstatistiksel Sınıflaması) tanı sınıflandırma tablosuna göre benzer tanı gruplarından hasta bakan bölümlerin sınıflandırılması amaçlanmıştır. Bu sayede benzer hastalıklara bakan bölümlerin benzer gereksinimlerinin rahatıkla karşılanabilmesi ve birlikte çalışabilirlikte kolaylık yaratmak amaçlanmıştır. Ülkemizde ICD - 10 tanı gruplarının kullanımı, 2005 yılından itibaren kullanımı zorunlu hale gelmiştir [14]. Çalışmada bu değişkenin kullanılabilmesi için bölüme göre veri tabanından çekilen tanı grubu listesi incelenmiştir. $C$ tanı gruplu kanser hastalarına ek olarak, M (Kas iskelet sistemi ve bağ dokusu hastalıkları), I (Dolaşım sistemi hastalıkları) ve $\mathrm{N}$ (Genitoüriner sistem hastalıkları) tanı gruplarının [15] birden farklı bölüm tarafından kullanıldığı tespit edilmiştir ve analize katılmıştır. Diğer tanı gruplarının birden fazla bölüm tarafından kullanım oranları yetersiz görüldüğü için incelemeye alınmamıştır.

Yaş ortalaması: Yaşlı hastalarda hareket kabiliyetine uygun, asansöre yakın ve tekerlekli sandalyeileulaşımı kolayalanlaroluşturulmalıdır. Ayrıca çocuk ve bebek hastaların sıklıkla kullandığı bölümler için oyun alanları ve bakım odalarına sahip alanlar oluşturulmalıdır. Bu sebeplerden dolayı yaş ortalaması değişkeni analize eklenmiştir. Cinsiyet, Eğitim düzeyi, Medeni hali, Mesleği, Doğum yeri değişkenleri her ne kadar hastalar önemli demografik özellikler içerisinde nitelendirilebilse de, gerek çalışmanın amacına uygun olmadığı gerekse de ilgili alanlara ait eksik kayıtların fazla olması sebebiyle incelemeye alınmamıştır.

Veriler değişken kümelerine ait bölüm değerleri açısından da tek tek detaylı olarak incelenmiştir. İlgili bölüm öğretim üyelerinin uzman görüşüne başvurularak burada olabilecek uygunsuz değerler düzeltilmiş ya da sorgu işlemleri bu veriler dışarıda bırakılarak tekrarlanmıştır. Örneğin Kadın Doğum bölümüne ait radyoloji tetkik sayılarının normalden yüksek olduğu uzman görüşüyle tespit edilmiştir. Kaynak veri seti incelendiğinde, Radyolojik işlemlerin SUT (Sağlık Uygulama Tebliği) temel alınarak oluşturulduğu görülmüştür. Detaylı incelemede bu işlemlerin tamamının radyoloji bölümünde yapılmadığı, ilgili poliklinikten ayrılmadan yaptırılan işlemlerin de bulunduğu tespit edilmiştir. Çalışmanın amacına aykırı hasta dolaşımına yol açmayan bu durumun bölüm içerisinde yapılan ultrason işlemlerinden kaynaklandığı anlaşılarak veri setinden çıkarılmıştır. Değişkenlerin analize hazır hale getirilen son verileri tabloda listelenmiştir (Tablo 1). Uzman doktorlar tarafından analiz aşamasında yapılan değerlendirmede, Kas iskelet sistemi tanılı değişkenden eklem rahatsızlıklarına ait verilerin çıkarılması durumunda daha anlamlı bir küme tablosu oluştuğu belirlenmiş ve sonuçlar bu duruma göre paylaşımıştır.

\section{Bulgular}

Çalışmanın bu kısmında kümeleme analizinin sonuçları verilmiştir. Kümeleme analizinde, başlangıçta her bir birim ayrı bir küme olarak kabul edilmekte olup birim sayısı kadar küme oluşmaktadır. Sonraki adımda en yakın iki birim birleştirilerek küme sayısı azaltılmaktadır. Sürekli tekrarlanan bu ikinci adım neticesinde son olarak tüm birimler tek küme altında toplanmaktadır [16].

Ward's kümeleme metodu ve kareli öklit uzaklığına göre SPSS'de yapılan analiz neticesinde yığılma tablosu (Agglomeration Schedule) ortaya konmuştur (Tablo 2). Her bir satırda birimlerin oluşturduğu küme aşamaları yer almaktadır. İlk satırda ilk aşamada birleşen ve birbirine en çok benzeyen iki bölüm (Endokrinoloji, İç hastalıkları) yer almaktadır. Birbirine en az benzeşen iki bölüm ise son aşamada görülen (Aile hekimliği, Radyasyon Onkolojisi) bölümleridir. Katsayılar sütunu küme oluşturan birimler arasındaki kareli öklit uzaklıklarını göstermektedir. Sonraki sütunda o satırda yer alan kümenin hangi aşamada oluştuğu görülmektedir. Sonda yer alan sonraki aşama sütununda ise o satırdaki birimlere bir diğer birimin hangi aşamada eklendiği gösterilmektedir. $\mathrm{Bu}$ tablonun katsayılar sütununda meydana gelen büyük artışlar küme sayısı göstergesi olarak kabul edilmektedir [17].

Hiyerarşik kümeleme tekniğinde küme sayısını belirlemek için yığılma tablosunun yanı sıra ağaç diyagramı (dendrogram) da kullanılmaktadır. Dendrogramlar 0 ila 25 birim arası ölçeklendirilirler. Dikey çizgiler birleşen birimlerin oluşturduğu kümeleri, yataydakiler ise kümeler arasındaki mesafeyi gösterir [16]. Birbirine en çok benzeyen bölümler bir birimlik 


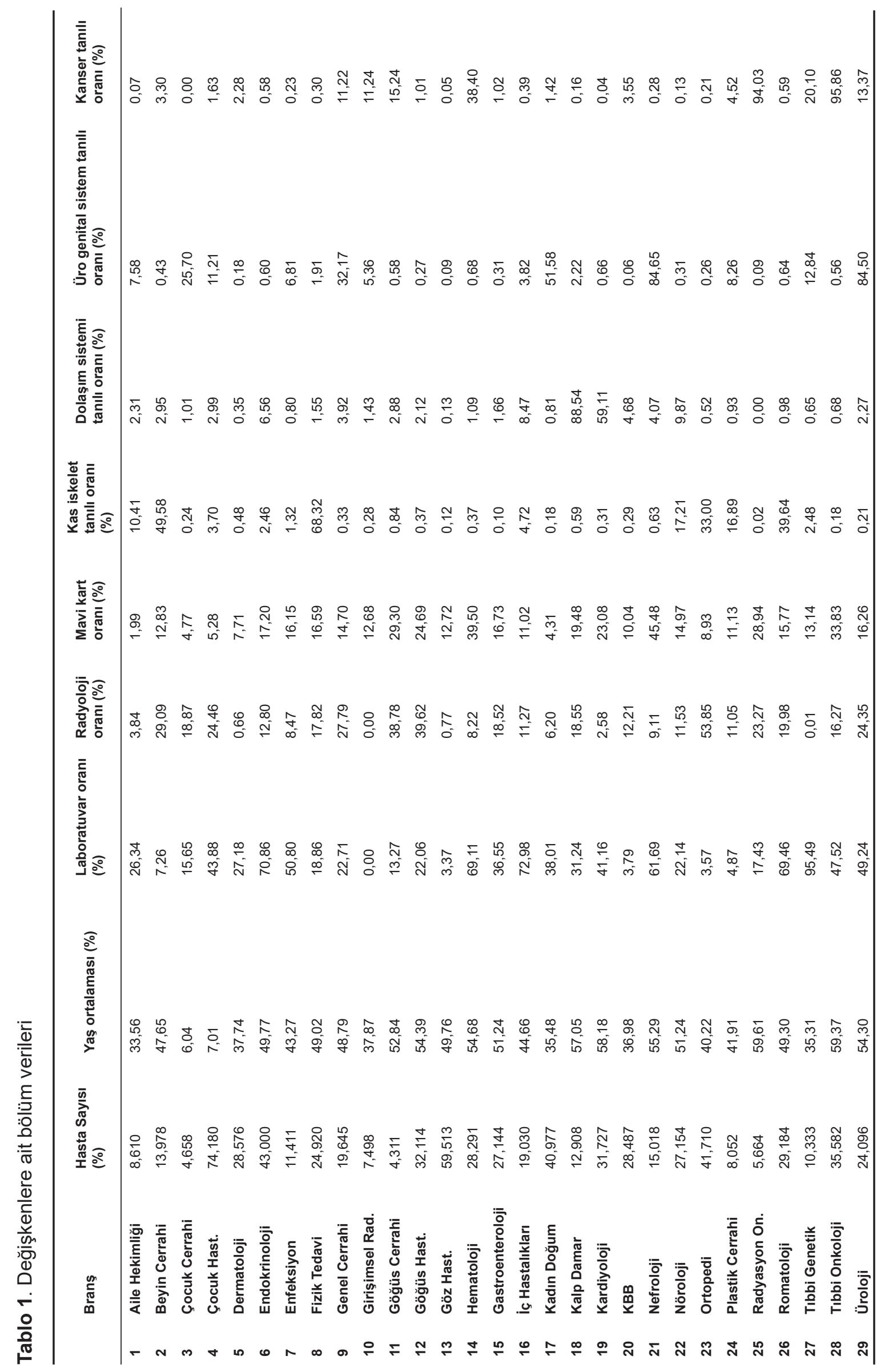


Tablo 2. Yığılma tablosu

\begin{tabular}{|c|c|c|c|c|c|c|}
\hline \multirow{2}{*}{ Aşama } & \multicolumn{2}{|c|}{ Birleştirilmiş Küme } & \multirow{2}{*}{ Katsayılar } & \multicolumn{2}{|c|}{ Kümenin İlk Görüldüğü Aşama } & \multirow{2}{*}{ Sonraki Aşama } \\
\hline & Küme 1 & Küme 2 & & Küme 1 & Küme 2 & \\
\hline 1 & 6 & 16 & 45,150 & 0 & 0 & 17 \\
\hline 2 & 10 & 27 & 133,552 & 0 & 0 & 9 \\
\hline 3 & 1 & 5 & 245,102 & 0 & 0 & 10 \\
\hline 4 & 11 & 12 & 397,608 & 0 & 0 & 21 \\
\hline 5 & 13 & 20 & 564,879 & 0 & 0 & 7 \\
\hline 6 & 7 & 15 & 771,391 & 0 & 0 & 15 \\
\hline 7 & 13 & 24 & 1024,464 & 5 & 0 & 9 \\
\hline 8 & 2 & 8 & 1345,427 & 0 & 0 & 18 \\
\hline 9 & 10 & 13 & 1748,136 & 2 & 7 & 22 \\
\hline 10 & 1 & 22 & 2200,208 & 3 & 0 & 15 \\
\hline 11 & 25 & 28 & 2691,426 & 0 & 0 & 28 \\
\hline 12 & 3 & 4 & 3220,372 & 0 & 0 & 20 \\
\hline 13 & 18 & 19 & 3838,539 & 0 & 0 & 25 \\
\hline 14 & 21 & 29 & 4546,957 & 0 & 0 & 26 \\
\hline 15 & 1 & 7 & 5267,000 & 10 & 6 & 21 \\
\hline 16 & 9 & 17 & 6000,904 & 0 & 0 & 20 \\
\hline 17 & 6 & 26 & 6948,279 & 1 & 0 & 19 \\
\hline 18 & 2 & 23 & 8143,565 & 8 & 0 & 24 \\
\hline 19 & 6 & 14 & 9939,459 & 17 & 0 & 25 \\
\hline 20 & 3 & 9 & 11831,641 & 12 & 16 & 23 \\
\hline 21 & 1 & 11 & 14107,014 & 15 & 4 & 22 \\
\hline 22 & 1 & 10 & 16619,921 & 21 & 9 & 23 \\
\hline 23 & 1 & 3 & 20662,045 & 22 & 20 & 24 \\
\hline 24 & 1 & 2 & 27856,998 & 23 & 18 & 27 \\
\hline 25 & 6 & 18 & 36280,920 & 19 & 13 & 26 \\
\hline 26 & 6 & 21 & 47826,280 & 25 & 14 & 27 \\
\hline 27 & 1 & 6 & 61319,693 & 24 & 26 & 28 \\
\hline 28 & 1 & 25 & 77926,000 & 27 & 11 & 0 \\
\hline
\end{tabular}

mesafede en az benzeyenleri ise 25 birimlik mesafede birleşmektedirler. Yapılan analiz sonucunda elde edilen dendrogram bir birimlik mesafe için incelendiğinde 16 farklı kümenin oluştuğu görülmektedir (Şekil 1). Küme sayısı 5 birimlik mesafede 7 ye inmektedir. Ancak bu mesafede, bir kümedeki bölüm sayısı 12 olduğu ve yeterli ayrışmanın sağlanamadığı görüldüğü için 4 birimlik mesafe referans noktası olarak belirlenmiştir. Bu mesafede küme sayısının 9 olduğu dendrogramdan görülmektedir. Sonuçlar yığışma tablosunda büyük artış durumuyla da uyum göstermektedir (Tablo 2).
Dendrogramda gözlemlediğimiz ilk kümeyi örnek olarak açıklayacak olursak; küme elemanlarının İç hastalıkları genel bilim dalı, Endokrinoloji, Romatoloji ve Hematoloji gibi İç hastalıkları Anabilim Dalının alt bilim dallarından oluştuğu görülmektedir (Şekil 1). Bu kümenin oluşturduğu bölümlerin ortak özellikleri ise Laboratuvar istemlerinin ortalamaya göre çok fazla olması ve hasta yaş ortalamalarının da orta yaş ve üstü olmasıdır. Çalışmada, tüm kümelerin hangi bölümlerden oluştuğu ve hangi değişkenlerin ağırlıklı olarak bu kümelerin oluşmasında yardımcı olduğu bilgisi de verilmiştir (Tablo 3). 
Dendrogram using Ward Linkage

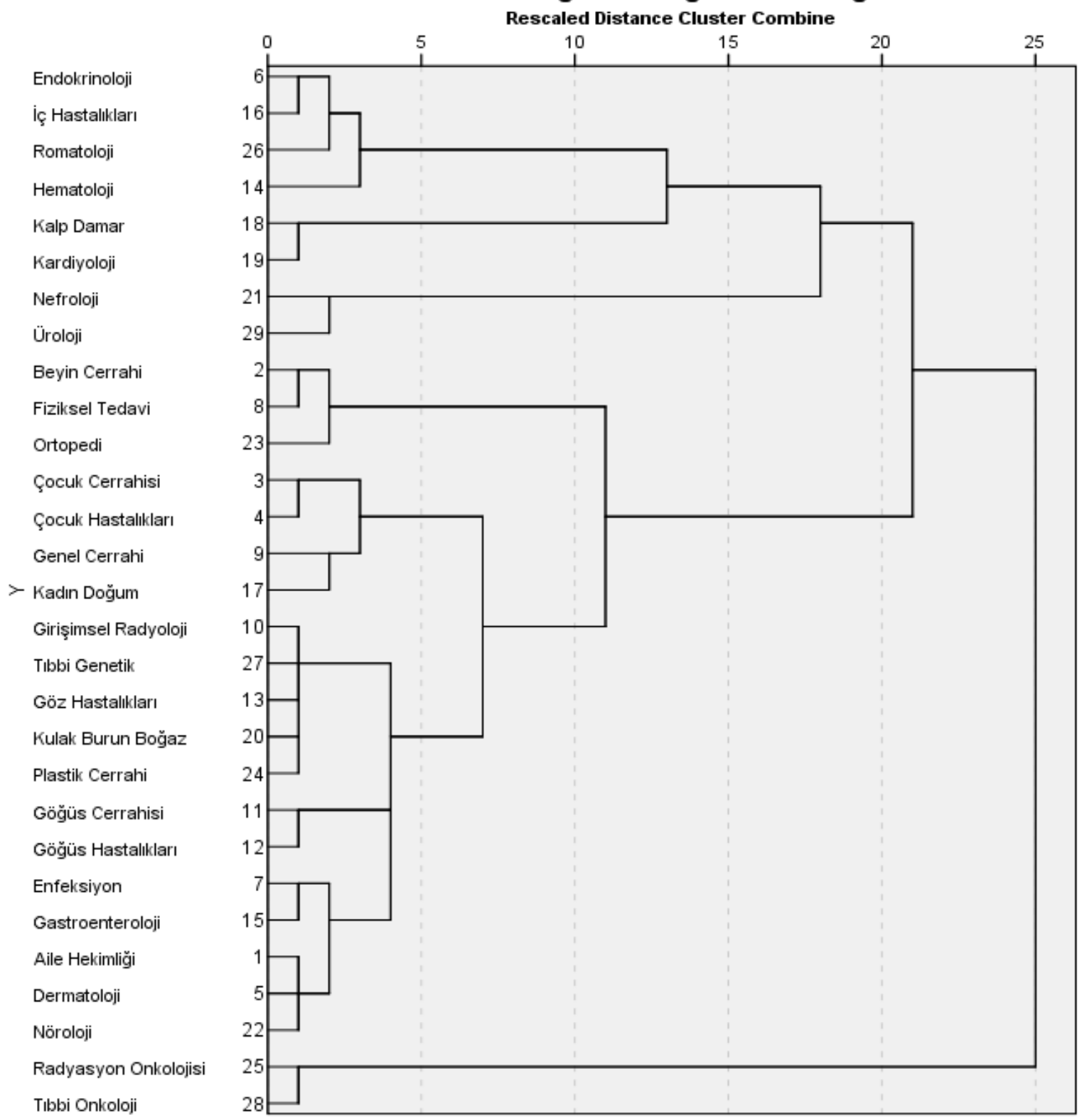

Şekil 1. Ward's (varyans) yöntemi kullanarak oluşturulan dendrogram 
Tablo 3. Küme değişken ilişkileri

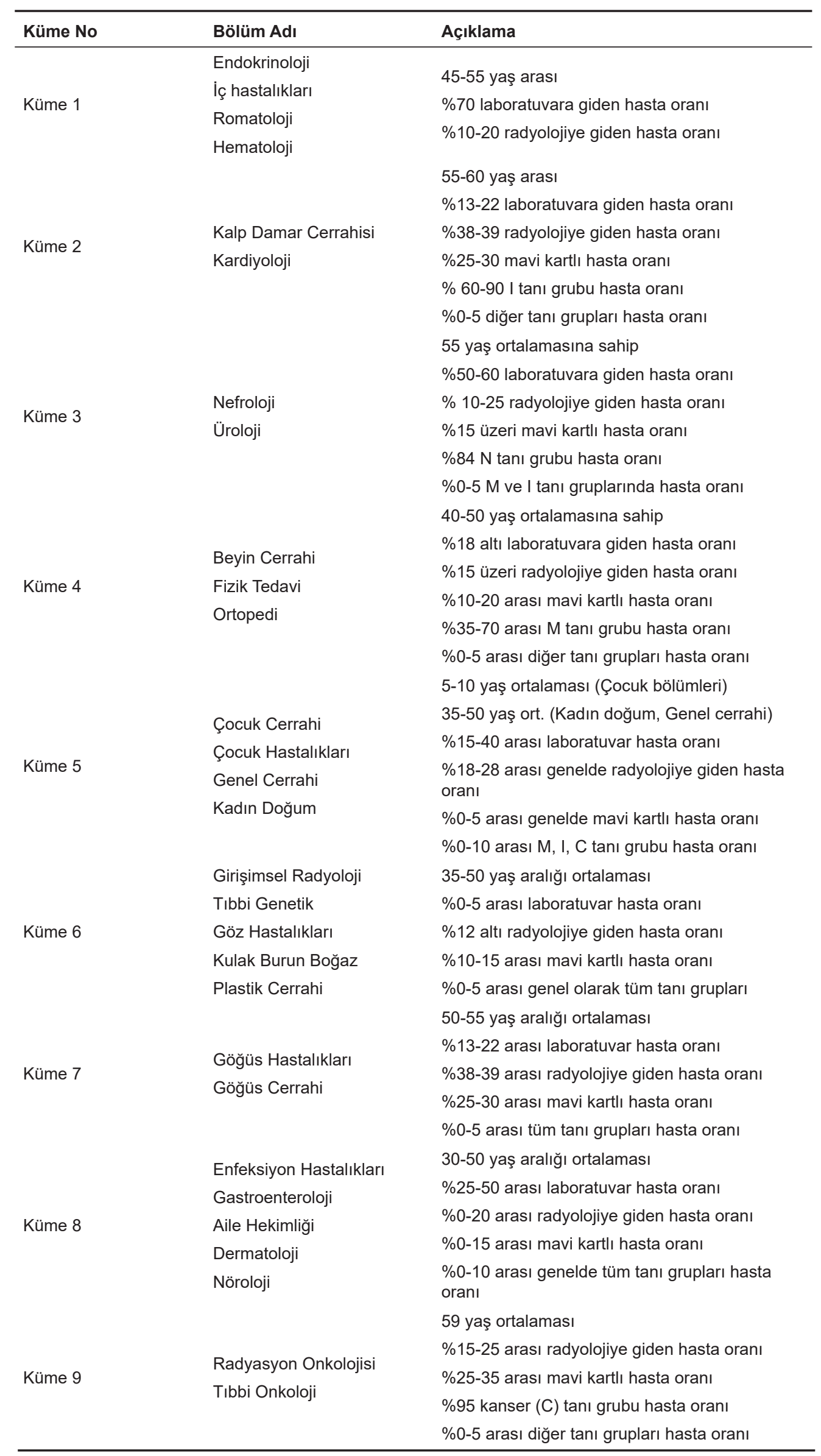




\section{Küme hasta sayıları}

Hasta sayısı diğerlerinden fazla olan kümelere ait bölümleri, hastanenin girişine uzak bir noktaya yerleştirmek, mekânların organizasyonu açısından büyük bir yanlış olacağı için çalışmada, amaca uygun olarak elde edilen kümeler hasta sayılarına göre de incelenmiştir. Bu noktada sonuçların daha doğru bir şekilde yorumlanabilmesi için elde edilen kümelerin toplam hasta sayıları ortaya konmuştur (Tablo 4).

Tablo 4. Küme hasta sayıları

\begin{tabular}{ll}
\hline Kümeler & Hasta Sayısı \\
\hline Küme 1 & 119,505 \\
Küme 2 & 44,635 \\
Küme 3 & 39,114 \\
Küme 4 & 80,608 \\
Küme 5 & 139,460 \\
Küme 6 & 113,883 \\
Küme 7 & 36,425 \\
Küme 8 & 102,895 \\
Küme 9 & 41,246 \\
Toplam & $\mathbf{7 1 7 , 7 7 1}$ \\
\hline
\end{tabular}

Hasta sayıları incelendiğinde Küme 1, Küme 5 , Küme 6 ve Küme 8 kümelerinin sayıları diğerlerine göre yüksek olup girişe yakın, kolay ulaşılır bir noktaya konumlandırılması önerilmektedir. Küme 2, Küme 3, Küme 4, Küme 7 ve Küme 9 ise diğerlerine göre daha az sayıda hasta sayısına sahip olduğu için daha uzak noktalarda konumlanabilir.

$\mathrm{Bu}$ noktada hasta sayısının belirleyici tek değişken olamayacağını tekrar belirtmek gerekir. Küme değişken ilişkileri tablosundan da (Tablo 3) görülebileceği üzere Küme 9'da baskın olan değişkenlerden biri kanser tanılı hastalar iken bir diğeri yüksek yaş ortalamasıdır. Hasta sayısı düşük de olsa bu bölüm kümesi girişten kolay ulaşılabilir yerde konumlanmalıdır. Benzer durum yaşlı ve dolaşım hastalıkları tanı grubu hasta sayısı fazla olan Küme 2 için de geçerlidir.

\section{Tartışma}

Çalışmamızda elde edilen tüm bulgular ışığında Pamukkale Üniversitesi Tıp Fakültesi Hastanesi'nin mevcut poliklinik yerleşimini (Tablo 5) değerlendirecek olursak; Radyoloji ve Onkoloji binasının ağırlıklı olarak kanser hastalarının tedavisi amacıyla tahsis edilmiş ayrı bir bina olduğu görülmektedir. Buradaki yerleşim çalışmadaki Küme 9 ile örtüşmektedir. Ancak bu binada yer verilen Hematoloji bölümünün her ne kadar kanser hastaları yoğun olsa da (\%40), Küme 9 üyesi olan bölümlerin yoğunluğuna (\%95) sahip olmadığı için analiz sonucu olarak başka bir kümede yer almıştır.

Analiz sonuçları ile mevcut durumun tam olarak örtüştüğü gruplar arandığında Küme 2 (Kardiyoloji-Kalp Damar Cerrahi) ve Küme 7 (Göğüs Hastalıkları-Göğüs Cerrahi) bölümleri belirgin bir şekilde ortaya çıkmaktadır. Bu bölümler Kırmızı binanın aynı katında ve farklı koridorlarında bir arada çalışma şartına uymaktadırlar. Kırmızı bina 2. kattaki Kulak Burun Boğaz, Göz bölümlerine ek olarak hemen bir üst kattaki Plastik Cerrahi bölümü analiz sonuçlarındaki Küme 6'nın elemanlarındandır. Kırmızı bina zemin katındaki Ortopedi, Fizik Tedavi ve bitişiğindeki mavi binanın yine zemin katında bulunan Beyin Cerrahi bölümleri, analiz sonucuna göre Küme 4'ü oluşturmaktadır. Bu yapılanma aynı alanda bulunma şartına asgari uyum sağlamaktadırlar.

Analizde bir arada bulunan Küme 1 bölümlerinden İç Hastalıkları ve Hematoloji tamamen farklı lokasyonlarda olsalar da, Endokrinoloji ve Romatoloji bölümleri mevcut bina yerleşiminde de (Mavi Bina Kat 3) bir arada bulunmaktadır. Hasta yoğunluğuna göre iki kata yayılmış olan Genel Cerrahi, Kadın Doğum, Çocuk Hastalıkları ve Çocuk Cerrahi bölümleri aynı kümede (Küme 5) yer almakta olup, yine mevcut yerleşke durumunun analiz sonucuyla uyumlu olduğu görülmektedir. Mavi Bina Zemin kattaki Enfeksiyon, Aile Hekimliği, Nöroloji bölümleri ise Küme 8'in elemanları olup bunlara geniş işlem odalarından dolayı hemen bir alt katta yer verilen yine aynı kümenin elemanı Gastroenteroloji bölümü de eklenebilir. Bu kümenin elemanlarının bir arada bulunma koşulu büyük çoğunlukla (Dermatoloji hariç) mevcut durumda sağlanmaktadır.

Elde edilen analiz sonuçlarına göre Pamukkale Üniversitesi Tıp Fakültesi Hastanesi'nin düzeltilmesi gereken olumsuz yönleri de mevcuttur. Örneğin kanser hastalarının yoğunlukta bakıldığı analizimizde de ağırlıklı olarak Küme 9'u temsil eden Radyoloji ve Onkoloji binası ana poliklinik girişinden ve 
Tablo 5. Hastane poliklinik yerleşkesi

\begin{tabular}{ll}
\hline Kat & Radyoloji ve Onkoloji Binası \\
\hline Kat 1 & Hematoloji - Girişimsel Radyoloji \\
Zemin & Onkoloji \\
Kat -1 & Radyasyon Onkolojisi \\
Kat & Bağlantı Bloğu Binası \\
Kat 2 & Tıbbi Genetik \\
Kat 1 & İç Hastalıkları \\
Kat & Kırmızı Bina Poliklinik Binası 1 \\
Kat 3 & Dermatoloji - Plastik Cerrahi - Üroloji \\
Kat 2 & Kulak Burun Boğaz - Göz \\
Kat 1 & Göğüs Hastalıkları - Göğüs Cerrahi - Kalp Damar Cerrahisi - Kardiyoloji \\
Zemin & Ortopedi - Fizik Tedavi \\
Kat & Mavi Bina Poliklinik Binası 2 \\
Kat 3 & Romatoloji - Endokrinoloji \\
Kat 2 & Genel Cerrahi - Kadın Doğum \\
Kat 1 & Çocuk Cerrahi - Çocuk Hastalıkları \\
Zemin & Nöroloji - Aile Hekimliği - Beyin Cerrahi - Enfeksiyon \\
Kat -1 & Gastroenteroloji - Nefroloji \\
\hline
\end{tabular}

numune alım noktasından uzaktadır. Bu sorunun giderilmesi adına, güvenlik zafiyeti oluştursa da binaya ayrı bir giriş verilerek dışarıdan gelenler için ulaşım süresinin azaltılmak istendiği gözlenmiştir. Bu durum toplu taşıma ile gelen hastaların ulaşımını kolaylaştırsa da otoparklara olan uzaklık sebebiyle taksi ya da şahsi aracını kullanan hastaların ulaşımını zorlaştırmaktadır. Ayrıca binanın Onkoloji bölümünün olduğu katta ayrı bir kan alma noktası oluşturulmuştur. Ancak burası da sadece kan örneklerinin alınması için sabahları çalışmaktadır. Harici durumlar için hastalar yine merkezi numune alım noktasına gitmek için uzun bir yol kat etmektedirler.

Bir diğer değinilmesi gereken husus Çocuk bölümlerinin hasta sayıları ile karşılaştırılamayacak bir şekilde zeminde olmayan tek bir katta toplanmış olmasıdır. Bu durumun gereksiz hasta trafiğine ve asansör kullanımına yol açmaması imkânsızdır. Ayrıca hastaların yaşları düşünüldüğünde ses kirliliği ve kaosun da oluşması muhtemeldir. Tavsiye edilen Çocuk bölümlerinin uygun kısımlarının yine 1. Katta bırakılırken büyük bir bölümünün zemin kata yerleşimidir. Şartların uygun olması durumunda tam olarak yapılması gereken ise tıpkı Onkoloji binasında olduğu gibi Çocuk Hastalıklarının birlikte çalışabilirliğe uygun Kadın Doğum gibi diğer bölümlerle birlikte ayrı bir bina içinde yer almasıdır. Buraya tüm örneklerin verilebildiği tam zamanlı çalışan bir numune alma yeri de oluşturulmalıdır. Bu şekilde bir yerleşim, Kulak Burun Boğaz ve Göz Hastalıkları gibi hasta sayısı yüksek bölümlere de (Küme 6) girişe ve zemine yakın noktalardan yer açılmasını sağlayacaktır.

Sonuç olarak, çalışmada veri madenciliği yöntemlerinden kümeleme analizi kullanılarak poliklinik bölümlerinin hasta profillerine göre sınıflandırılması sağlanmıştır. Toplamda incelenen 17 değişken ve 700 binden fazla hasta verisi üzerinde yapılan analiz sonucunda en uygun çözüm olarak 9 bölüm kümesi belirlenmiştir.

Özet olarak, mevcut poliklinik yerleşkesi, analiz sonucu ortaya çıkan 9 kümeden 8'inde tam ya da kısmi uyum göstermektedir. Sadece Küme 3'te (Nefroloji, Üroloji) benzer bir yerleşim sağlanmamıştır. Analiz sonuçlarına göre hasta sayısı yüksek olan dört kümeden (Küme 1, 5, 6,8 ) sadece biri (Küme 8) mevcut durumda da 
girişe yakın lokasyonda bulunmaktadır. Diğer üç kümede hasta sayısının dengelenmesi amacıyla, küme elemanlarından bazılarına bir alt/üst katta yer verildiği gözlenmektedir ki bu da analiz sonuçlarının mimari yapıya uygun hale getirilmesi şeklinde yorumlanabilir.

Çalışmayı varılmak istenen amaçlara ulaşma açısından değerlendirdiğimizde, yapılan analiz bölümlerin hasta profillerine göre oluşturdukları kümeleri ortaya çıkarmıştır. Bu kümeler hasta sayıları açısından da incelenmiştir. Devamında elde edilen bulgularla mevcut fiziksel yerleşim karşılaştırılmıştır. Bu çerçevede, çalışmanın ileride ihtiyaç duyulması halinde aynı hastanede yer değişikliği planlamaları ve personel, cihaz gibi kaynak dağılımlarında kullanılmasının önü açıktır. Ayrıca bulguların verilerin üçüncü basamak bir hastaneden elde edilmesi gibi bazı sınırlılıklar göz önünde bulundurularak diğer bölge ve/veya üniversite hastanelerinde karar destek verisi olarak kullanılmasının da önünde bir engel bulunmamaktadır. Kullanılan değişkenler 17 örnek arasından seçilen en uygun 9 tanesi olup, değişken seçiminde erişebilirlik, bütünlük, amaçlara uygunluk ve verilerin doğrulanabilir olmasına dikkat edilmiştir.

Literatürdeki sağlık göstergeleri kullanılarak yapılan kümeleme analizi çalışmalarından inceleyecek olursak, Alptekin [18] tarafından 27 Avrupa ülkesi ve Türkiye'nin verilen 7 sağlık göstergesi bulanık kümeleme analizi yöntemiyle karşılaştırılmıştır. Kullanılan değişkenler doğumda yıl bazında yaşam beklentisi, doğumda sağlıklı yaşam beklentisi, 5 yaşın altındaki çocuklarda ölüm oranı, 15-69 yaş arası yetişkin ölüm hızı, sağlık harcamalarının Gayri Safi Milli Hasıla (GSMH) oranı, kişi başına düşen toplam sağlık harcaması ve hükümetin yaptığı sağlık harcamasının toplam sağlık harcamasına oranıdır. Çalışmanın sonucunda 28 ülke iki farklı kümeye ayrılmıştır ve Türkiye'nin yetişkin ölüm hızında, kişi başına düşen toplam sağlık harcamasında ve doğumdaki yaşam beklentisinde iyileştirme yapması gerektiği sonucuna varılmıştır.

Sağlık alanında kümeleme analizi ile yapılan bir diğer çalışmada [10], 2010 yılına ait 81 ilimizin 10 farklı sağlık değişkeni kullanılarak yedi, on ve on beş kümeden oluşan üç farklı senaryo incelenmiştir. Genel olarak gelişmiş ve az gelişmiş illerimiz kendi aralarında gruplanmışlardır. Az gelişmiş iller genellikle
Güneydoğu Anadolu ve Doğu Anadolu bölgesi illerinden oluşmaktadır. Sonuç olarak bölgesel ve iktisadi gelişmişlik farkılıkları, sağlık noktasında da önemli farklııılara yol açmaktadır.

Benzer bir çalışma 2013 yılına ait 16 farklı sağlık göstergesi ile Tekin [19] tarafından gerçekleştirilmiştir. 81 il 5, 7 ve 11 adet üç farklı küme çözümüne göre incelenmiştir. Her ne kadar sağlık değişkenleri açısından doğu ve batı illeri arasındaki gelişmişlik farkı bu çalışmada da ortaya konsa da, il kümelenmelerinde veri dönemleri ve değişkenler arasındaki farklılıklar yüzünden oluştuğu düşünülen ciddi ayrımlar görülmektedir.

Bir diğer çalışmada, Ekonomik Kalkınma ve İşbirliği Örgütü Ülkeleri (OECD) verileri hiyerarşik kümeleme analizi yöntemi yardımıyla incelenmiş ve 4 farklı kümenin oluştuğu görülmüştür. Çalışma diğerlerinden kullanılan sağlık değişkenlerinin kümeler arasında farklılık oluşturup oluşturmadığının Kruskal Wallis /Mann Whitney $U$ testleriyle incelenmesi yönünden ayrışmaktadır. Toplam on iki sağlık göstergesinden onunun kümeler arasında anlamlı farklılık gösterdiği ve bu nedenle ilgili değişkenlerin OECD ülkelerinin kümelenmesinde belirleyici özellik taşıdığı belirtilmektedir [12].

Sağlık alanında kümeleme analiziyle yapılan ve ülkelerin, illerin sağlık gelişmişliklerinin ortaya konması amaçlanan bu çalışmalarda, her ne kadar çalışmamıza örnek oluştursa da, kullanılan değişkenler ve varılmak istenen amaç tamamen farklıdır.

Norveç'te yapılan bir başka çalışmada; 4 farklı sağlık bölgesinde 61 hastaneden taburcu olmuş 23.420 hastaya, posta yoluyla anket gönderilmiştir. Psikiyatri ve Pediatri departmanlarının kapsam dışı bırakıldığı çalışmada kümeleme analizi yapılmıştır. Geri dönüş yapan 10.514 hasta cevabından elde edilen veriler, "mükemmel hizmetler" den "verilen hizmetlerde açık bir şekilde iyileştirmeye intiyaç var" a kadar 5 ayrı kümeye ayrıştırılarak gruplanmıştır. Ayrıca bir küme oluşturmayacak kadar heterojen olan ve hizmetlerin tüm sonuç ve öğelerinde çok zayıf olduğunu belirten aykırı bir grup da belirlenmiştir. Elde edilen kümeler yaş, eğitim, kendi kendine algılanan sağlık, cinsiyet ve ankete açık yorum yazma derecesi ile önemli derecede ilişkili bulunmuştur [20]. Bu çalışma 
ise genel hasta memnuniyeti, tedaviden alınan yarar ve malpraktis algısı üzerine düzenlenmiş olup çalışmamızdaki varılmak istenen amaçlarla benzerlik göstermemektedir.

Bircan ve Çam [21] çalışmasında, Cumhuriyet Üniversitesi Hastanesi'ne 2011 yılında başvuran toplam 78.239 hastanın kayıtlarını kümeleme analizi yöntemleriyle incelemiştir. K-Means ve yoğunluk tabanlı kümeleme algoritmalarına göre 11 farklı değişkene (yaş, tedavi ücreti, il dışında yaşam vb.) göre yapılan analizde, K-Means kümeleme sonuçlarına göre hasta profilleri 3 farkı kümeye ayrılırken, daha uygun sonuçlar bulunduğu ifade edilen yoğunluğa dayalı kümeleme yöntemine göre 2 farklı küme oluşmuştur. Bu çalışmada da hasta başvuru davranışlarının belirlenmesi amaçlanmış olup değişkenler araştırmamız ile uyuşmamaktadır.

Bu çalışmayla benzer hasta profiline hizmet veren bölümlerin gruplanması amaçlanmıştır. Literatür incelendiğinde kümeleme analizi yöntemi kullanarak, poliklinik hizmeti veren bölümlerin fiziksel olarak yerleşkede ne şekilde yer alması ve hasta profillerine uygun olarak personel/ekipman desteğinin nasıl özelleştirilmesi gibi problemlere çözüm arayan; bu amaçla demografik özellikler, tanısal gruplar ve tetkik istem sıklıkları değişkenlerini analiz eden bir çalışmaya rastlanmamıştır.

Çalışmada literatürde örneğine rastlanmayan üniversite hastanelerinde bölüm poliklinikleri yerleşimlerinin sağık değişkenlerine göre kümeleme analizi ile incelenmesi başarıyla gerçekleştirilmiştir. Veri madenciliği sağlık alanında farklı alanlarda kullanılmış olsa da, çalışmayla özellikle hasta dolaşımı ve bölümlerin birlikte çalışabilirliği açısından literatüre katkıda bulunulmuştur.

Çalışmanın önemli kısıtıklarından biri analizin üçüncü basamak bir üniversite hastanesinde yapılmasıdır. Üçüncü basamak hastaneler, ileri tetkik ve özel tedavi gerektiren hastaların bakıldığı, bunun için intiyaç duyulan yüksek teknoloji, altyapı ve uzman kadroya sahip araştırma hastaneleridir. Bu yüzden ikinci ve üçüncü basamak hastane bölümlerinin hasta profilleri birbirinden farklı olabilmektedir. Dolayısıyla elde edilen sonuçlar öncelikle üçüncü basamak hastaneler için geçerlidir. Ayrıca bölgesel olarak değişen hasta profilleri, bunlara bağlı olarak bölümlerin ekstra intiyaç duyabileceği geniş üniteler ve tıbbi cihazlar da sonuçlarda değişikliğe yol açabilir. Değinilmesi gereken bir diğer önemli kısıt, tek bir hastanenin verilerinin kullanılmasıdır. Bölgedeki birden fazla benzer hastanenin verilerine ulaşılması durumunda ortak hasta profilleri çıkarılabilir.

Kümeleme analizi yöntemiyle birçok hastane yerleşim planı hastalar açısından daha kolay faydalanılabilir hale getirilebilir.

Çıkar ilişkisi: Yazarlar çıkar ilişkisi olmadığını beyan eder.

\section{Kaynaklar}

1. İleri Y. Sağlık kurumlarında yönetimsel etkinlik ve yerleşim planının önemi. Konya, Eğitim Yayınevi, 2018.

2. Türkmen NA. Hastane iş akış ve yerleşim değerlendirmesi. Yüksek Lisans Tezi. Çukurova Üniversitesi Fen Bilimleri Enstitüsü, Endüstri Mühendisliği Anabilim Dalı, Adana, 2007.

3. Çetik MO, Oğulata SN. Hastane hizmet birimleri arasında iş akışının ergonomik açıdan düzenlenmesi. Standart Ekonomik ve Teknik Dergi 2002;41:28-35.

4. Kokoç M. Acil servis yerleşim planlamasında veri madenciliği yaklaşımı: kırıkkale üniversitesi tıp fakültesi hastanesi'nde bir uygulama. Yüksek Lisans Tezi. Kırıkkale Üniversitesi Fen Bilimleri Enstitüsü, Endüstri Mühendisliği Anabilim Dalı, Kırıkkale, 2017.

5. Koh HC, Tan G. Data mining applications in healthcare. J Healthc Inf Manag 2011;19:64-72.

6. Uysal FN, Ersöz T, Ersöz F. Türkiye'deki illerin yaşam endeksinin çok değişkenli istatistik yöntemlerle incelenmesi. EBD 2017;9:49-65.

7. Tekin B. Covıd-19 pandemisi döneminde ülkelerin covid-19, sağlık ve finansal göstergeler bağlamında sınıflandırılması: hiyerarşik kümeleme analizi. FESA Dergisi 2020;5:336-349. https://doi.org/10.29106/ fesa. 738322

8. Yaz HF. Çok değişkenli istatistiksel yöntemlerden kümeleme analizi; spss ile bir uygulama. Erişim adresi: https://www.academia.edu/7276743/çok_değişkenli_ istatistiksel_yöntemlerden_kümeleme_analizi_spss_ ile_bir_uygulama. Erişim tarihi 08 Nisan 2021

9. Ak B. SPSS uygulamalı çok değişkenli istatistik teknikleri. Ed. Kalaycı Ş. Ankara, Asil Yayın Dağıtım, 2010:65-69.

10. Çelik Ş. Kümeleme analizi ile sağıık göstergelerine göre Türkiye'deki illerin sınıflandırılması. Doğuş Üniversitesi Dergisi 2013;14:175-194.

11. Haşıloğlu SB. Algı haritalarının değerlendirilmesi için kümeleme algoritmalarına dayalı yeni bir model geliştirilmesi. Yüksek Lisans Tezi. Pamukkale Üniversitesi Fen Bilimleri Enstitüsü, Bilgisayar Mühendisliği Anabilim Dalı, Denizli, 2017. 
12. Sonğur C. Sağlık göstergelerine göre ekonomik kalkınma ve işbirliği örgütü ülkelerinin kümeleme analizi. SGD 2016;6:197-224.

13. Öz B, Taban S, Kar M. Kümeleme analizi ile Türkiye ve $A B$ ülkelerinin beşeri sermaye göstergeleri açısından karşılaştırılması. Eskişehir Osmangazi Üniversitesi Sosyal Bilimler Dergisi 2008;10:1-30.

14. Öz S, Karagöz R, Altındiş S, et al. ICD-10 tanı kodlama sistemine aile hekimlerinin bakışı. Kocaeli Üniversitesi Sağlık Bilimleri Dergisi 2019;5:1-4. https://doi. org/10.30934/kusbed.444479

15. Sağlık Bakanlığı. ICD-10-TRM hastalık ve sağlık girişimi sınıflandırma sistemleri geliştirilmesi. Erişim adresi: https://shgmsgudb.saglik.gov.tr/tr,6220/icd-10trm-hastalik-ve-saglik-girisimi-siniflandirma-sistemlerigelistirilmesi.html. Erişim tarihi 01 Ekim 2021

16. Özer $A$, Öztürk $M$, Kaya $A$. İşletmelerde etkinlik ve performans ölçmede VZA, kümeleme ve TOPSis analizlerinin kullanımı: IMKB işletmeleri üzerine bir uygulama. Atatürk Üniversitesi Sosyal Bilimler Enstitüsü Dergisi 2010;14:233-260.

17. Gençoğlu P. Türkiye'de illerin gelişmişlik düzeyi dikkate alınarak sağlık hizmetlerinin kümeleme analizi aracılığıyla değerlendirilmesi. ERÜ iliBFD 2018;52:301324. https://doi.org/10.18070/erciyesiibd.323409

18. Alptekin N. Comparıson of Turkey and European Unıon Countries' Health indicators by using fuzzy clustering analysis. IJBSR 2014;4:68-74. https://doi. org/10.18533/ijbsr.v4i10.607

19. Tekin B. Temel sağlık göstergeleri açısından Türkiye'deki illerin gruplandırıması: bir kümeleme analizi uygulaması. Çankırı Karatekin Üniversitesi İktisadi ve İdari Bilimler Fakültesi Dergisi 2015;5:389416. https://doi.org/10.18074/cnuiibf.196

20. Bjertnaes O, Skudal KE, Iversen $\mathrm{HH}$. Classification of patients based on their evaluation of hospital outcomes: cluster analysis following a national survey in norway. BMC Health Serv Res 2013;13:73. https:// doi.org/10.1186/1472-6963-13-73

21. Bircan $H$, Çam S. Veri madenciliğinde kümeleme analizi ve sağlık sektöründe bir uygulaması. CÜ İktisadi ve İdari Bilimler Dergisi 2016;17:85-96.

Etik kurul onayı: Çalışma için, Pamukkale Üniversitesi Girişimsel Olmayan Klinik Araştırmalar Etik Kurulu'ndan 25.05.2021 tarih ve 56367 sayı numarasıyla onay alınmıştır.

\section{Yazarların makaleye olan katkıları}

M.T. çalışmanın problemini ve ana fikrini kurgulamıştır. M.T ve Ö.Ö. teoriyi geliştirmiş ve gereç yöntem bölümünü düzenlemiştir. Bulgular kısmındaki verilerin değerlendirmesini yazarlar birlikte yapmışlardır. Makale M.T. tarafından yazıımış, Ö.Ö. gözden geçirip gerekli düzeltmeleri yapmış ve onaylamıştır. Ayrıca tüm yazarlar çalışmanın tamamını tartışmış ve son halini onaylamıştır.

Teşekkür: Prof. Dr. Selçuk Yüksel'e makaledeki kritik değerlendirme, öneri ve düzeltmeleri için teşekkür ederiz. 